\title{
Microbiological assay on microtitre plates of folate in serum and red cells
}

\author{
S O’Broin, B Kelleher
}

\begin{abstract}
Aims: To develop a simple microbiological assay for serum and red cell folates on 96-well microtitre plates, suitable for use in routine clinical diagnosis.

Methods: Use of a chloramphenicol resistant organism (NCIB 10463) saved time by avoiding aseptic precautions. Use of plate sealers facilitated mixing. Evaluation of assay performance included estimations of folate recovery, assay reproducibility, and response to reduced folate. Results obtained on sera (193) and red cell folates (150) were compared with those obtained using a traditional microbiological assay.

Results: Good recovery of folic acid added to serum and also good interassay and intra-assay precision were obtained with both serum $(\mathrm{CV} \%$ of $<5)$ and red cell folate pools (CV\% of $<5)$. Equimolar assay responses were obtained with folic acid, 5-formyltetrahydrofolate (L-form), and 5-methyltetrahydrofolate (L-form). The microassay correlated well with a traditional assay for estimation of folate in both serum $(n=193, r=0.975)$ and red cells ( $n=150, r=0.96)$.

Conclusions: This assay is more compact and less time consuming than the traditional assay. It is extremely economical and is easy to perform in a routine clinical laboratory.
\end{abstract}

Estimations of blood folate, whether in serum or red cells, remain crucial in the differential diagnosis of nutritional anaemia. Although most clinical laboratories assay folates using commercially available techniques incorporating competitive protein binding, a few prefer to use the microbiological assay with Lactobacillus casei, which is the reference method. In 1987 improvements in microtitre plate technology facilitated the development of a microbiological assay for food folates on these plates. ${ }^{1}$ Subsequently Horne and Patterson ${ }^{2}$ reported a similar plate assay which was simpler, with cryopreservation of the organism (ATCC 7469) and a shortened incubation time. This assay could be used to estimate serum folates. We now report a microbiological assay for folates on microtitre plates using a chloramphenicol resistant strain of $L$ casei (NCIB 10463). The assay can be used to determine concentrations of both serum and red cell folate of patient samples. It is technically simpler than previously published techniques.

\section{Methods}

Lactobacillus casei (NCIB 10463) was obtained from Torrey Research Station (Aberdeen, Scotland). Vitamin folic acid assay broth was obtained from Merck (Darmstadt, Germany). Flat-bottomed microtitre plates $(0.396 \mathrm{ml}$ capacity) were from A/S Nunc (Roskilde, Denmark) and mylar plate sealers were from Dynatech Laboratories (Chantilly, Virginia 22021, USA). Chloramphenicol was from Parke Davis \& Co. (Pontypool, Gwent, Wales) and $\beta$-lactamase (EC $3 \cdot 5 \cdot 2 \cdot 6)$ ex Bacillus cereus was supplied by Koch Light Ltd (Suffolk, England). Microtubes ( $2 \mathrm{ml}$ capacity) for storing cryopreserved organisms were obtained from Sarstedt Ltd (Wexford, Ireland). Ascorbic acid, sodium ascorbate, folic acid [PteGlu], DL-5-methyltetrahydrofolate (sodium salt), and folinic acid (calcium salt) were from Sigma (London). Folate standard concentrations were verified spectrophotometrically ${ }^{3}$ using a Beckman model $35 \mathrm{UV} / \mathrm{Vis}$ spectrophotometer. ${ }^{3}$ Culture tubes $(13 \times 100 \mathrm{~mm})$ were from Corning (UK). Stericol disinfectant was obtained from Sterling Medicare (Guildford, Surrey, England). Additions of dilute sera, whole blood haemolysates, and folates were made with a Stepper semiautomated pipette (Socorex, Renens, Switzerland). Inoculated assay medium was dispensed using an eightchannel Titertek dispenser and plates were read on a Titertek Multiscan Plus Mark 2 plate reader, both from Flow Laboratories (Ayrshire, Scotland). All other chemicals were of reagent grade and distilled water was used throughout.

\section{PREPARATION OF SAMPLES}

Lysates of red cell folates were prepared by dilution of whole blood anticoagulated with EDTA 1 in 10 with freshly prepared $1 \%$ ascorbic acid, ${ }^{4}$ mixing thoroughly, and incubating at $37^{\circ} \mathrm{C}$ for 30 minutes. These lysates could then be stored at $-20^{\circ} \mathrm{C}$. Serum was separated and stored at $-20^{\circ} \mathrm{C}$ until assay. The standard precautions against infection by high risk samples were taken with all samples, both in sample preparation and throughout the assay. 
the methods of Grossowitz ${ }^{5}$ as described for $L$ casei (ATCC 7469), and modified by Wilson and Horne. ${ }^{6}$ This cryopreserved culture was stored at $-70^{\circ} \mathrm{C}$ in $1 \mathrm{ml}$ aliquots. Reconstituted assay medium was seeded by thawing a phial of cryopreserved culture rapidly (in a water bath at $37^{\circ} \mathrm{C}$ ), adding to the bulk assay medium at the concentration of $200 \mu 1 / 100 \mathrm{ml}$, and mixing very thoroughly using a magnetic stirrer.

\section{MICTOTITRE PLATE ASSAY PROCEDURE}

A fresh solution of sodium ascorbate $(0.5 \%)$ was made and used to dilute serum samples 1 in $20(100 \mu \mathrm{l}$ up to $2 \mathrm{ml})$ and red cell lysates (as described above) were diluted 1 in 40 ( $50 \mu \mathrm{l}$ up to $2 \mathrm{ml}$ ). Dilute sera were mixed and added to four plate wells (100 $\mu$ l to each of two wells and $50 \mu \mathrm{l}$ to each of the other two). A compensating volume of $50 \mu \mathrm{l}$ of fresh $0.5 \%$ sodium ascorbate was added to make the volume in all wells up to $100 \mu \mathrm{l}$. Dilute red cell lysates were mixed and added to six wells ( $100 \mu \mathrm{l}$ to each of three wells and $50 \mu \mathrm{l}$ to each of the remaining three). The additional well at each dilution was to act as a subtractable blank value to compensate for the colour contribution of lysate haemoglobin. Compensating volumes of $0.5 \%$ sodium ascorbate were added to make all wells up to $100 \mu \mathrm{l}$ volume.

\section{ASSAY STANDARDS}

A working standard solution of folic acid $(500 \mathrm{pg} / \mathrm{ml})$ was made by dilution of a stock standard in $0.5 \%$ sodium ascorbate. Additions of this standard were made to the wells to give a range of concentrations from $0-50 \mathrm{pg} /$ well (0-100 $\mu \mathrm{l}$ of standard). All well volumes were made up to $100 \mu \mathrm{l}$ with $0.5 \%$ sodium ascorbate.

\section{ASSAY MEDIUM}

Medium was reconstituted in distilled water by adding $5.7 \mathrm{~g}$ vitamin folic acid assay broth, $3 \mathrm{mg}$ chloramphenicol, and $30 \mu \mathrm{l}$ Tween 80 per $100 \mathrm{ml}$ medium. After mixing, heating to boiling, and cooling, ascorbic acid $(75 \mathrm{mg} /$ $100 \mathrm{ml}$ ) was added. Finally, the assay organism was added as described above. Medium was stirred continuously while being dispensed into the microtitre plate wells at the rate of $200 \mu \mathrm{l} /$ well. An addition of $10 \mu \mathrm{l}$ of dilute Stericol disinfectant ( 1 in 25 dilution) was made to several zero tubes of the standard curve to act as assay blanks. Similar additions of disinfectant were made to the blank wells, one at each dilution. This addition of disinfectant had the effect of preventing organism growth without contributing to the optical density of the blanks. It thus avoided the need for dispensing unseeded medium into these blanks with the hazard of cross-contamination with organism from adjacent wells. All plates were sealed firmly with plate sealers, mixed by inversion, and incubated in a warm air cupboard (not humidified) at $37^{\circ} \mathrm{C}$ in the dark for 42 hours. They were then mixed thoroughly by inversion, the plate sealers removed and read at $570 \mathrm{~nm}$. It is important to ensure that there are no bubbles over the wells while reading, as these can alter the reading and, if they burst, can soil the optics of the reader.

\section{CALCULATION OF RESULTS}

The results lend themselves readily to data reduction. The appropriate dilution factors were used to calculate serum folate ( 1 in 200 and 1 in 400) and whole blood folate (1 in 400 and 1 in 800 ) concentrations. Red cell folates were calculated from the values for whole blood folate, serum folate, and from the packed cell volume (PCV). The results were expressed as folate concentration per $\mathrm{ml}$ of packed red cells. ${ }^{4}$

\section{Results}

EVALUATION OF ASSAY RESPONSE TO REDUCED FOLATE MONOGLUTAMATES

The response of the assay organism to the reduced folate monoglutamates folinic acid (5formyl tetrahydrofolate) and 5-methyltetrahydrofolate were compared with that of folic acid (PteGlu). Reduced folate standards were diluted in sodium ascorbate $(500 \mathrm{mg} / 100 \mathrm{ml})$ to equimolar concentrations of biologically active l-isomer. Comparison of the growth responses of these folates with that of folic acid under the conditions of the assay gave similar results (fig 1).

\section{ASSAY PERFORMANCE}

The reproducibility of the plate assay was monitored using control sera and red cell lysates ( 1 in 10, whole blood:ascorbate). These were stored at $-20^{\circ} \mathrm{C}$. Reproducibility of these pools within and between assays were estimated. The results show good reproducibility and are expressed in tables 1 and 2 . When folic acid was added to serum at five different concentrations $(n=10$ in each case), its recovery ranged from $94 \cdot 1$ to $102 \%$ of the expected value, with a mean of $98 \cdot 4 \%$.

COMPARISON OF RESULTS USING A TRADITIONAL ASSAY

The results of assays for serum and red cell

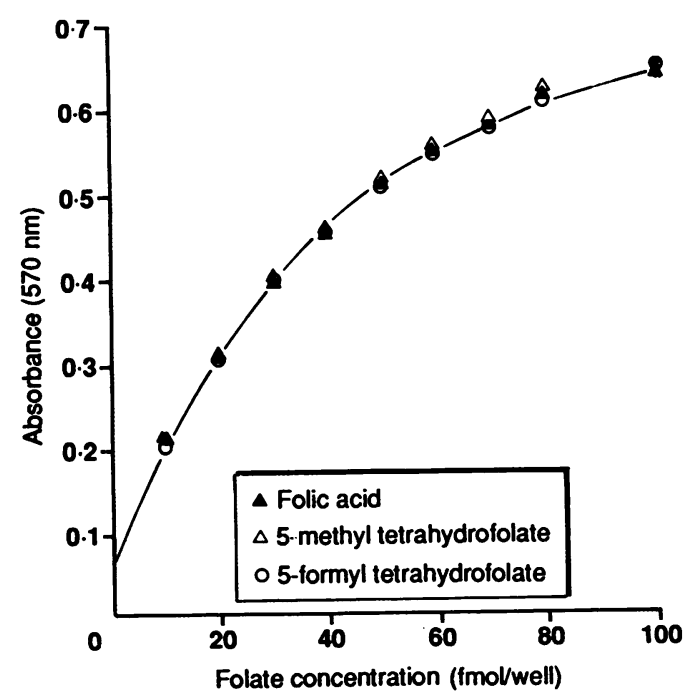

Figure 1 Growth response of $L$ casei (NCIB 10463) on microtitre plates to folic acid, 5-methyltetrahydrofolate and 5-formyltetrahydrofolate. 
Table 1 Between assay reproducibility of control values for folate in serum and whole blood $(n=10$ in each case $)$

\begin{tabular}{lllll}
\hline \multicolumn{2}{l}{ Serum folates $(\mu \mathrm{g} / l)$} & & \multicolumn{2}{c}{ Whole blood folates $(\mu \mathrm{g} / \mathrm{l})$} \\
\cline { 1 - 2 } \cline { 5 - 5 } Mean & $C V \%$ & & Mean & $C V \%$ \\
\hline 1.6 & 4.9 & & 48.9 & 6.5 \\
2.5 & 4.8 & & 88.1 & 6.6 \\
3.4 & 3.86 & & 140.7 & 5.4 \\
4.5 & 2.7 & 178.8 & 3.1 \\
\hline
\end{tabular}

Table 2 Intra-assay reproducibility of control values for folate in serum and red cells $(n=12$ in each case $)$

\begin{tabular}{lllll}
\hline \multicolumn{2}{l}{ Serum folates $(\mu \mathrm{g} / l)$} & & \multicolumn{2}{c}{ Whole blood folates $(\mu \mathrm{g} / \mathrm{l})$} \\
\cline { 1 - 2 } \cline { 5 - 5 } Mean & $C V \%$ & & Mean & $C V \%$ \\
\hline 1.87 & 3.7 & 69.7 & 4.7 \\
3.35 & 2.05 & & 30.7 & 5.1 \\
4.51 & 6.2 & 49.4 & 4.9 \\
\hline
\end{tabular}

folates by a microtitre plate assay were compared with those obtained using a traditional tube assay. ${ }^{7}$ The tube assay was completed in soda glass culture tubes $(13 \times 100 \mathrm{~mm})$ using the same cryopreserved organism. The results showed good correlation for both serum folates $(\mathrm{n}=193, \mathrm{r}=0.975)$ and red cell folates ( $n=150, r=0.96$ ) (fig 2). The similarity of results obtained between these assays meant that no adjustment of the normal ranges of blood folate values was necessary, and in this laboratory we consider serum folate values of $<2.4 \mu \mathrm{g} / 1$ and red cell folate values of $<100 \mu \mathrm{g} / 1$ of packed cells to be deficient. Each laboratory, however, should calculate its own ranges of values.

\section{EFFECT OF ANTIBIOTICS ON THE ASSAY}

Antibiotics can interfere with microbiological assays. Some $77(2 \%)$ of 3860 sequential diagnostic serum folate assays showed evidence of such interference and seven of these were due to methotrexate. These cases were identified by

Figure 2 Comparison of estimations of serum folate $(A)$ and whole blood folate $(B)$ using a traditional tube assay and the microtitre plate assay.

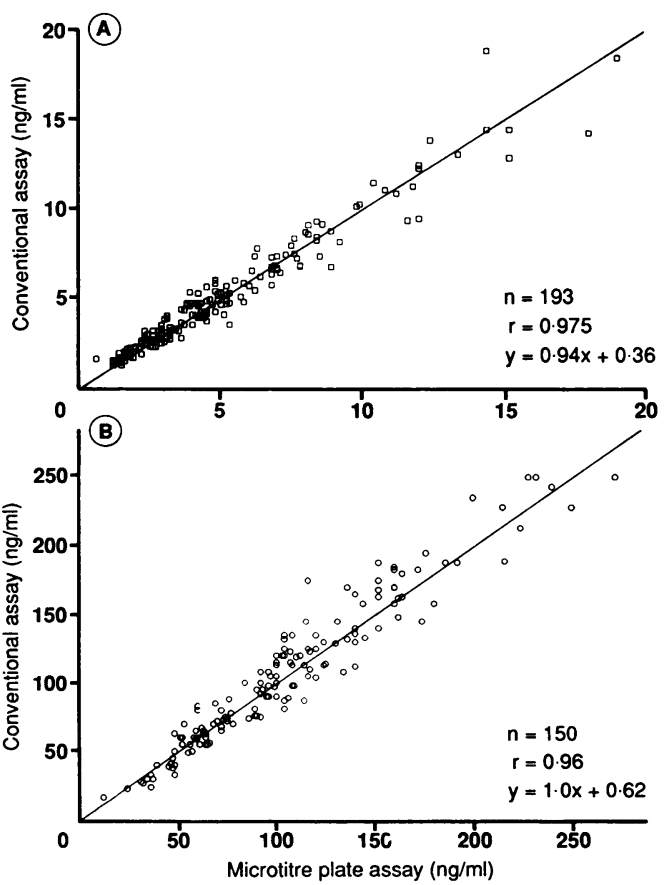

either the complete inhibition of organism growth or a partial inhibition which created a discrepancy in the results of two dilutions. No interference was noted with red cell folate assays over this period, probably due to the pre-assay dilution factor for red cell folates being some 20 -fold higher than that for serum. We have since noted occasional inhibition due to methotrexate. Serum preincubation with a $\beta$-lactamase preparation had been shown to eliminate interference caused by penicillins, augmentin, and third generation cephalosporins in a vitamin B12 microbiological assay using $L$ leichmanii. ${ }^{8}$ The efficiency of $\beta$ lactamase in eliminating antibiotic interference in this assay was evaluated in a pilot study by determining the recovery of a spike of folic acid after lactamase treatment. Sera suspected of containing interfering antibiotics were diluted in three separate tubes for repeat assay. Tube $A$ contained serum $(50 \mu \mathrm{l})$, tube $\mathrm{B}$ contained serum $(50 \mu \mathrm{l})$ with $\beta$-lactamase stock solution $(20 \mu \mathrm{l})$, and tube $\mathrm{C}$ was similar to tube $\mathrm{B}$ with an added spike of folic acid. Tubes were mixed, incubated $\left(15\right.$ minutes at $37^{\circ} \mathrm{C}$ ), diluted to $1 \mathrm{ml}$ with sodium ascorbate $(500 \mathrm{mg} / 100 \mathrm{ml})$ and assayed. The result of tube $A$ confirmed the antibiotic intereference and a good recovery of folate from tube $\mathrm{C}$ confirmed the validity of the serum folate result of tube B. A study of 30 such samples which arrived sequentially into the laboratory showed good recovery of added folic acid (mean $99.5 \%$, CV\% 15). This confirmed the potential of $\beta$-lactamase in treating samples containing antibiotics and such treatment of selected samples (or all samples) can save delays caused by having to repeat assays. Further studies using patient sera and in vitro additions of antibiotics to normal sera will be necessary to optimise this procedure.

\section{Discussion}

The recent emergence of microbiological assays for vitamins on microtitre plates ${ }^{129}$ owes much to advances in microtitre plate technology and to improved optical qualities of the plates. The obvious advantages of such miniaturisation of the assays include not only speed of reading and reduced reagent costs but also these simplified assays have become less exclusive and are incorporated more readily into the modern clinical or research laboratory.

In introducing such an assay for food folate analysis Newman and Tsai suggested that use of organism cryopreservation and also assay with an antibiotic resistant organism would further simplify the assay. ${ }^{1}$ The folate assay subsequently introduced by Horne and Patterson took advantage of organism cryopreservation but retained the traditional organism (ATCC 7469) which necessitated sterilisation of reagents by filtration and stringent aseptic precautions. ${ }^{2}$ The assay presented here is simpler than previously published assays and is suitable for routine diagnostic estimation of folate in serum and red cells. Use of a chloramphenicol-resistant strain of $L$ casei (NCIB 10463) allows it to be completed openly on the laboratory bench. The plates are covered with 
plate sealers which avoids the use of a humidified incubator and permits easy mixing by inversion both before incubation and reading. The results of this assay correlate well with those of a traditional assay in the estimation of both serum $(r=0.975, n=193)$ and red cell folates $(r=0.97, n=150)$. An equimolar assay response was obtained for both folic acid (pteroylglutamic acid) and the reduced folate monoglutamates; 5-formyltetrahydrofolate (folinic acid), and 5-methyltetrahydrofolate, signifying that the assay will neither under-nor overestimate these reduced derivatives. The assay also shows acceptable reproducibility of values for the folate pool of both serum and red cells (tables 1 and 2) and good recovery of folic acid $(98.4 \%)$ from serum. A pilot study indicates that it may be possible to assay certain occasional samples which contain high concentrations of antibiotics. This will be investigated further.

Microbiological assay using $L$ case $i$ has long been accepted as the reference method for routine diagnostic investigations of folate concentration. However, such microbiological assays have been difficult to carry out routinely in the general clinical laboratory setting. The assay described is within the competence of any routine clinical laboratory, has extremely low operating costs, and is particularly well suited to handling large volumes of samples.

1 Newman EM, Tsai JF. Microbiological analysis of 5formyltetrahydrofolic acid and other folates using an automatic 96-well plate reader. Anal Biochem 1987; 154:509-15.

2 Horne DW, Patterson D. Lactobacillus casei microbiological assay of folic acid derivatives in 96-well

3 Blakley RL. The biochemistry of folic acid and related pteridines. In: Neuberger A, Tatum EL, eds. Frontiers of biology. London: North Holland, 1969:91-5.

4 Hoffbrand AV, Newcombe BFA, Mollin DL. Method of assay of red cell folate activity and the value of the assay as a test for folate deficiency. J Clin Pathol 1966;19:17-28.

5 Grossowitz N, Waxman S, Schreiber C. Cryoprotected Lactobacillus casei: an approach to standardisation of microbiological assay of folic acid in serum. Clin Chem 1981;27:745-7.

6 Wilson SD, Horne DW. Use of glycerol-cryoprotected Lactobacillus casei for microbiological assay of folic acid. Clin Chem 1982;28:1198-200.

7 O'Broin serum folate estimations using two different methods. $J$ Clin Pathol 1973;26:80-1.

8 Kelleher BP, Scott JM, O'Broin SD. Use of beta-lactamase to hydrolyse interfering antibiotics in vitamin B12 microbiological assay using Lactobacillus leichmanii. Clin Lab Haematol 1990;12:87-95.

9 Kelleher BP, O'Broin SD. Microbiological assay for vitamin $B_{12}$ performed in 96-well microtitre plates. J Clin Pathol 1991;44:592-5. 